\title{
Herpes zoster in patients with systemic lupus erythematosus
}

\section{Maria Bibiana Leroux}

\author{
Centro de Referencia en Raynaud y Colagenopatías, Rosario, Argentina
}

Corresponding author: Dra. Maria Bibiana Leroux, E-mail: leroux_mb@hotmail.com

Sir,

The onset of cutaneous herpes zoster (HZ) is due to a reactivation of the varicella zoster virus and it is characterized by a painful vesicular eruption following one or more dermatomes. Post herpetic neuralgia, the most common complication could develop persisting during months or even years. The HZ it is considered the most frequent viral etiology affecting patients with systemic lupus erythematosus (SLE).

Recently, Borda et al. describe the epidemiological characteristics of $\mathrm{HZ}$ in a Brazilian population affected with SLE. Fifty five episodes of HZ were reported in 51 patients. The onset of most of them was 5 years after the SLE diagnosis and frequently during inactive or mild activity. The majority of patients show a typical distribution and a good response to treatment. Nevertheless, complications such as secondary bacterial infection and post herpetic neuralgia could be present [1-3].

\section{INCIDENCE}

The HZ incidence is $1.2-4.9 / 1000$ affected individuals annually. In SLE patients is significantly higher reaching 16-22/1000 annually. It is to be noticed that is associated with abnormal cytotoxicity mediated by $\mathrm{T}$ cells and aggravated by treatment with corticoids and immunosuppressant $[1,2,4,5]$. Infection risk factors in patients with SLE in Table I. .

\section{CLINICS}

The classic HZ topography is in general unilateral affecting one dermatome, although $20 \%$ of patients could be extended to 3 contiguous dermatomes. Some authors classify this pattern as a disseminated HZ (Figs. la and b). A varicelliform eruption could be present in non selected patients and most frequently in immunocompromised ones. In cutaneous disseminated high risk patients visceral compromise i.e. disseminated intravascular clotting, encephalitis,

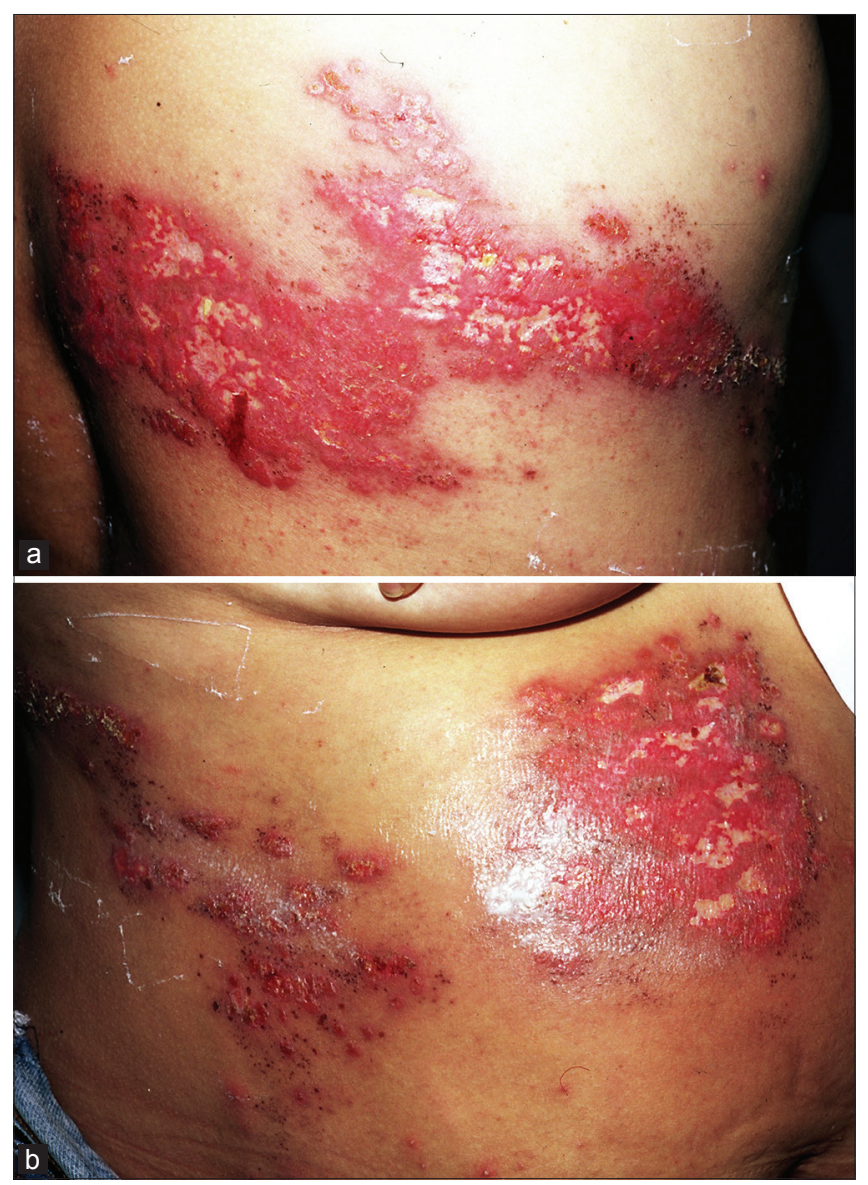

Figure 1a and b: Patient with systemic lupus erythematosus and severe disseminated herpes zoster in the body affecting three dermatomes. (T 7-8-9). a- Back. b- Trunk forehead. 
hepatitis, neumonitis and pancreatitis among others could complicate $[4,5]$.

Diagnostic methodology shown in Table 2 [1-6].

\section{TREATMENT}

It is strongly recommended to initiate antiviral treatment within 72 hours of rash onset. The drugs above mentioned shall be maintained for 7-10 days and for 2 days after all the lesions are covered by a crust (Tabl. 3) [1-4].

Primary medications for acute zoster-associated pain include: analgesics, neuro active and anticonvulsant agents. Prompt treatment of acute zoster and its associated pain can prevent the development of post herpetic neuralgia. Hospital admission should be considered in these cases:

Table 1: Infection risk factors in patients with systemic lupus erythematosus

\begin{tabular}{|ll|}
\hline Disease activity & Anti Sm DNA high titers \\
LES Nephritis & Low Complement levels \\
Hemolytic Anemia & Thrombocytopenia \\
Leucopenia & Antiphospholipid antibodies \\
Prednisone doses higher than $10 \mathrm{mg} / \mathrm{d}$ & Cyclophosphamid \\
Corticoids high pulse doses & Azathioprine \\
Micophenolate mofetil & Neoplasia history or present one actual \\
& \\
\hline
\end{tabular}

Table 2: Diagnostic methodology in herpes zoster

\begin{tabular}{l} 
- Tzanck test \\
- Serology \\
o IgM antibodies by Elisa Kit/recent infection \\
o IgG antibodies / previous contact \\
High antibodies titers could be detected $\mathrm{HZ}$ in its early onset \\
o Viral antigens by immunofluorescence \\
- PCR detection of viral DNA in vesicles aqueous solutions or in \\
cerebrospinal fluid. \\
$\begin{array}{l}\text { It is to take into account that the serological response could be altered in } \\
\text { immunodeprived patients. } \\
\text { Viral cultures are not a common daily practice. }\end{array}$ \\
\hline
\end{tabular}

Table 3: Treatment with antiviral drugs

\begin{tabular}{|c|c|}
\hline 1. Aciclovir & $\begin{array}{l}800 \mathrm{mg} 5 \text { times orally } \\
10 \mathrm{mg} / \mathrm{kg} \mathrm{IV} \mathrm{/} \mathrm{every} 8 \text { hours }\end{array}$ \\
\hline 2. Famciclovir & $500 \mathrm{mg}$ every 8 hours orally during 10 days \\
\hline 3. Valaciclovir & $1000 \mathrm{mg} / 8$ hours orally \\
\hline 4. Brivudina & $125 \mathrm{mg} / 6$ hours orally \\
\hline
\end{tabular}

severe symptoms, immunosuppression, significant bacterial super infection, disseminated herpes zoster, ophthalmic involvement or meningoencephalopathy involvement $[1-4,6,7]$.

\section{VACCINATION}

It was introduced in 2006. It is a live attenuated vaccine recommended for 60 years old patients comporting a reactivation risk. In these individuals a diminished HZ incidence $(50 \%)$ as well as post herpetic neuralgia has been observed (60\%). There is no clear evidence to recommend HZ vaccine in patients with SLE. There are researchers that propose that the same rule could be applied to the general population but only in those that are not medicated with immunosupressors before of after vaccination [6-7].

\section{CONCLUSION}

Herpes zoster can be a serious problem in systemic lupus erythematosus. Its complications and its antiviral treatment are known, however, the indication of the vaccine to prevent it is not recommended in all patients.

\section{REFERENCES}

1. Chen H-H, Chen Y-M, Chen T-J, Lan J-L, Lin C-H, Chen D-Y. Risk of herpes zoster in patients with systemic lupus erythematosus: a three-year follow-up study using a nationwide population-based cohort. Clinics. 2011;66:1177-82.

2. Navarra SV, Leynes MSN. Infections in systemic lupus erythematosus. Lupus. 2010;19:1419-24.

3. Danza A, Ruiz-Irastorza G. Infection risk in systemic lupus erythematosus patients: susceptibility factors and preventive strategies. Lupus. 2013;22:1286-94.

4. Ruiz-Irastorza G, Olivares N, Ruiz-Arruza I, Martinez-Berriotxoa A, Egurbide MV, Aguirre C. Predictors of major infections in systemic lupus erythematosus. Arthritis Res Ther. 2009;11:R109.

5. Tektonidou MG, Wang H, Dasgupta A, Ward MM. Burden of Serious Infections in Adults With Systemic Lupus Erythematosus: A National Population-Based Study, 1996-2011. Arthritis Care Res (Hoboken). 2015;67:1078-85.

6. Pasoto SG, Ribeiro ACM, Bonfa E. Update on infections and vaccinations in systemic lupus erythematosus and Sjogren's syndrome. Curr Opin Rheumatol. 2014;26:528-37.

7. Barbera C, Goldb WL, Fortin PR. Infections in the lupus patient: perspectives on prevention. Curr Opin Rheumatol. 2011;23:358-65.

Copyright by Maria Bibiana Leroux. This is an open access article distributed under the terms of the Creative Commons Attribution License, which permits unrestricted use, distribution, and reproduction in any medium, provided the original author and source are credited.

Source of Support: Nil, Conflict of Interest: None declared. 